\title{
Proximate Analysis and Heavy Metal Detection in Aquatic Plants of River Satluj, District Kasur
}

\author{
Muhammad Usman Taj", Sumaira Abass \\ Faculty of Fisheries and Wildife, University of veterinary and animal sciences, Lahore
}

*Corresponding Author: Muhammad Usman Taj, Faculty of Fisheries and Wildlife, University of veterinary and animal sciences, Lahore

\begin{abstract}
Present study was conducted at five study areas associated with river Satluj including the surroundings of leather tanning industry in District Kasur. Nagar village, Bhakhiwind, Ganda-Singh Wala, Wallaywala and Surroundings of Leather Tanning Industry. Samples of five species of aquatic plants and soil were collected from four study sites of river Satluj and Leather tanning industry at District Kasur. Three samples of each aquatic plant and soil were collected from each site. During the present study the proximate analysis of aquatic plants was as follows, the moisture contents of aquatic plants ranged between $(1.7 \pm 2.61 d$ to $7.9 \pm 2.61 a)$. The protein contents ranged between $(2.51 \pm 5.57 d$ to $22.14 \pm 0.7 a)$. The fat contents ranged between $(0.15 \pm 2.63 d$ to $6.9 \pm 2.77 a)$. The fiber contents of aquatic plants ranged between $(1.75 \pm 3.28 d$ to $16.14 \pm 4.8 \mathrm{a})$. The values of ash contents in aquatic plants ranged between $(1.62 \pm 8.54 d$ to $23.12 \pm 8.54 a)$. The data obtained after heavy metal detection revealed that in roots of most aquatic plants the metal accumulation occurs in order $\mathrm{Pb}>\mathrm{Cd}>\mathrm{Cr}$. In stems and leaves of aquatic plants the metal accumulation occurs in order $\mathrm{Pb}>\mathrm{Cr}>\mathrm{Cd}$. The accumulation of heavy metals in different fragments of aquatic plants occurs in order Roots $>$ Leaves $>$ Stems. During this study the lead limits were observed between $(0.28 \pm 0.001 d$ to $82.25 \pm 0.09 a)$, Cadmium values were recorded between $(0.11 \pm 0.001$ d to $9.82 \pm 0.05 a)$ and Chromium limits were observed between $(0.04 \pm 0.001 d$ to $11.61 \pm 0.02 a)$.
\end{abstract}

Keywords: Aquatic plants, Heavy metals, Spectrophotometer

\section{INTRODUCTION}

During last few decades the concern over the studies on some contaminants like, fertilizers, pesticides and trace metals and their impacts on environmental compartments such as soil, plants and water have attained a great significance. The lithogenic source is the reason of the presence of trace metals in environment and sometimes the concentration of metal fluxes in environment is increased by anthropogenic influences. The industrial activities are mainly included in the anthropogenic influences (Yanina et al. 2015).

The aquatic plants is a highly diverse group of plants around the globe. The community of the aquatic plants have a vast and diverse range of macrophytic organisms in it. The ferns, the mosses, the angiosperms, some macroalgae of freshwater and the liverworts have been collectively described as the aquatic plants. Aquatic plants occurs in the seasonally or permanently wet surroundings. In most of the wet lands, the aquatic plants have a remarkable population sizes (Lacoul and Freedman 2006; Chambers et al. 2008).

The growth rate of aquatic plants is very rapid in different aquatic bodies like waterways and lakes all over the world (Muhammed et al. 2012). The aquatic plants includes submerged, emergent and floating plants. These plants are a good source of food both for humans as well as other aquatic and terrestrial organisms. Some edible aquatic plants are a good source of proteins and nutrients. During the previous few years, the research for the inclusion of aquatic plants in the animal feed is going upgraded day-by-day (Tacon et al. 2009).

\section{Materials ANd Methods}

\subsection{Study Area}

Present Study Was Conducted At The Various Sites Associated With River Satluj Including The Surroundings Of Leather Tanning Industry In District Kasur. Following Five Sites Of District Kasur, On River Satluj, Was Considered As The Study Sites During The Present Study. 
Nagar Village, Bhakhiwind, Ganda-Singh Wala, Wallay Wala And Surroundings Of Leather Tanning Industry.

\subsection{Collection of Samples}

Samples of aquatic plants, contaminated soil and water were collected from four study sites of river Satluj and Leather tanning industry at District Kasur. Three samples of each aquatic plant and soil were collected from each site.

\subsection{Sample Preparation and Test}

The samples of aquatic plants were taken to the department of fisheries and aquaculture, UVAS, Ravi Campus Pattoki, for proximate analysis of different parts of aquatic plants (roots, stem and leaf) viz., moisture, ash, crude proteins, crude fats, and crude fibers. Different parts of aquatic plants viz., roots, stem and leaf were taken to laboratory of the department of Fisheries and research center, Manawa, Lahore, for the detection of heavy metals $(\mathrm{Pb}, \mathrm{Cd}$ and $\mathrm{Cr})$.

Soil samples were taken to the department of Fisheries and aquaculture, UVAS, Ravi Campus Pattoki, for determination of physico-chemical properties viz., sand, slit, clay, temperature, $\mathrm{pH}$, total alkalinity, electrical conductivity and total dissolved solids. The detection of heavy metals $(\mathrm{Pb}, \mathrm{Cd}$ and $\mathrm{Cr}$ ) from the soil samples was done at the above cited laboratories.

The obtained calculations was studied under Analysis of Variance (ANOVA) through SAS 9.1 statistical software and for comparing means LSD and Duncan's Multiple Range Test (DMRT) was applied (Duncan, 1955).

The obtained data will help the aquaculture scientists to understand the status of heavy metals accumulation in aquatic plants, associated soils and water, being parts of freshwater ecosystem.

\section{RESUlTS AND DiscUSSIONS}

\subsection{Proximate Analysis of Aquatic Plants}

The moisture contents of aquatic plants ranged between $(1.7 \pm 2.61 \mathrm{~d}$ to $7.9 \pm 2.61 \mathrm{a})$. The highest moisture was observed as (7.9 $\pm 2.61 \mathrm{a})$ in roots of Nymphae lotus at study area 3, Ganda-singh wala while the lowest moisture value was observed as (1.7 $\pm 2.61 \mathrm{~d})$ in roots of Eicchornia crassipes at study area 3, Ganda-singh wala. The protein contents ranged between $(2.51 \pm 5.57 \mathrm{~d}$ to $22.14 \pm 0.7 \mathrm{a})$. The highest value of protein was observed as $(22.14 \pm 0.7 \mathrm{a})$ in stem of Typha lagtifolia at study area 3, Ganda-singh wala while the lowest value was observed as $(2.51 \pm 5.57 \mathrm{~d})$ in roots of Eicchornia crassipes at study area 5, surroundings of leather tanning industry. The fat contents ranged between $(0.15 \pm 2.63 \mathrm{~d}$ to $6.9 \pm 2.77 \mathrm{a})$. The highest value of fat was observed as $(6.9 \pm 2.77 \mathrm{a})$ in leaves of Typha latifolia at study area 2, Bhakhiwind while the lowest value was observed as $(0.15 \pm 2.63 \mathrm{~d})$ in leaves of Potenderia chordata at study area 5, surrounding of leather tanning industry. The fiber contents of aquatic plants ranged between $(1.75 \pm 3.28 \mathrm{~d}$ to $16.14 \pm 4.8 \mathrm{a})$. The highest value of fiber was observed as (16.14 $\pm 4.8 \mathrm{a})$ in leaves of Nymphaea lotus at study area 4, Wallay wala while the lowest value of fiber was observed as $(1.75 \pm 3.28 \mathrm{~d})$ in stems of Eicchornia crassipes at study area 4, Wallay wala. The values of ash contents in aquatic plants ranged between

$(1.62 \pm 8.54 \mathrm{~d}$ to $23.12 \pm 8.54 \mathrm{a})$. The highest value was observed as $(23.12 \pm 8.54 \mathrm{a})$ in roots of Eicchornia crassipes at study area 5, surroundings of leather tanning industry while the lowest value was observed as $(1.62 \pm 8.54 \mathrm{~d})$ in roots of Nymphae lotus at study area 5, surroundings of leather tanning industry.

\subsection{Metal Detection in Aquatic Plants}

The data obtained by heavy metal detection (Lead, Cadmium and Chromium) in aquatic plants revealed significant differences $(\mathrm{p}<0.05)$ in $\mathrm{Pb}$ and $\mathrm{Cd}$ and $\mathrm{Cr}$. (Ingole et al. 2000) concluded that the huge magnitude of developing industrialization is responsible for increasing heavy metal pollution. The data obtained after heavy metal detection revealed that in roots most aquatic plants the metal accumulation occurs in order $\mathrm{Pb}>\mathrm{Cd}>\mathrm{Cr}$. In stems and leaves of aquatic plants the metal accumulation occurs in order $\mathrm{Pb}>\mathrm{Cr}>\mathrm{Cd}$. The accumulation of heavy metals in different fragments of aquatic plants occurs in order Roots $>$ Leaves $>$ Stems.

\subsection{Lead $(\mathrm{Pb})$}

Singh et al. (2012) stated that lead is such a fetal heavy metal which can cause adverse environmental and health effect even in low concentrations. David et al. (2003) narrated that lead is one of the highly toxic heavy metals, as it enters and absorbed in the body directly. Lead has an ability to be stored in 
bones, tooth and tissues as well. WHO (2004) stated that standard allowance of lead intake is 0.15 $\mathrm{mg} / \mathrm{L}$ and if the limit become exceeded then serious health issues like hepatitis and anemia may result. During present study the lead limits were observed between $(0.28 \pm 0.001 \mathrm{~d}$ to $82.25 \pm 0.09 \mathrm{a})$. The maximum value of lead was observed in roots of Eicchornia crassipes at study area 5, surroundings of leather tanning industry while the lowest value was observed in soil samples collected from study area 1, Nagar village.

\subsection{Cadmium (Cd)}

Wolverton and Rebecca (1978) ststed that cadmium is a highly toxic heavy metal for human life. Its exceeded limits can cause cancer, liver diseases, kidney diseases and cardiovascular issues and even very low concentrations can cause serious health issues. During present study the cadmium values were recorded between $(0.11 \pm 0.001 \mathrm{~d}$ to $9.82 \pm 0.05 \mathrm{a})$. The maximum value of cadmium was observed as $(9.82 \pm 0.05 \mathrm{a})$ in roots of nymphaea lotus at study area 5 , surroundings of leather tanning industry while the lowest value was noted as $(0.11 \pm 0.001 \mathrm{~d})$ in the soil samples collected from the study area 1 , Nagar village.

\subsection{Chromium $(\mathrm{Cr})$}

Chandra et al. (1997) stated that chromium is found naturally in animals plants and rocks. Although chromium is required by the biological systems of animals and humans as it cause breakdown of fats, proteins and sugars. It taken in excess then it causes serious health damages. During the present study, the chromium limits were observed between $(0.04 \pm 0.001 \mathrm{~d}$ to $11.61 \pm 0.02 \mathrm{a})$. The maximum value was observed as (11.61 $\pm 0.02 \mathrm{a})$ in roots of Potenderia chordata at study area 5, surroundings of leather tanning industry while the lowest value was observed as $(0.04 \pm 0.001 \mathrm{~d})$ in soil samples collected at study area 1 , Nagar village.

\subsection{Physico-Chemical Parameters of Soil}

Latha, (2016) concluded that water and sediment pollution has adversely affect the aquatic ecosystems by the discharge of industrial effluents in the natural water sources.cThe results of soil physico-chemical parameters revealed significant differences $(\mathrm{p}<0.05)$ in $\mathrm{pH}$, electrical conductivity, alkalinity, total dissolved solids, sand, silt and clay. The level of $\mathrm{pH}$ in soil ranged between $(5.9 \pm 0.01 \mathrm{a}$ to $7.89 \pm 0.01 \mathrm{~d})$. The highest value was observed as $(7.89 \pm 0.01 \mathrm{a})$ at study area 3 , Ganda-singh wala while the lowest value of $\mathrm{pH}$ was observed as $(5.9 \pm 0.01 \mathrm{~d})$ at study area 5 , surroundings of leather tanning industry. The electrical conductivity of soil ranged between (1989 $\pm 0.66 \mathrm{a}$ to $2138 \pm 0.66 \mathrm{~d})$. The highest value for soil electrical conductivity was noted as (2138 $\pm 0.66 \mathrm{a})$ at study area 3, Bhakhiwind while the lowest value was noted as $(1989 \pm 0.66 \mathrm{~d})$ at study area 4 , Wallay wala. The alkalinity level of soil samples ranged between $(114 \pm 0.77 \mathrm{a}$ to $187 \pm 0.77 \mathrm{~d})$. The highest value was observed as $(187 \pm 0.77 \mathrm{a})$ at study area 5 , surroundings of leather tanning industry while the lowest value of alkalinity was observed as $(114 \pm 0.77 \mathrm{~d})$ at study area 2 , Bhakhiwind. The level of total dissolved solids ranged between $(1810 \pm 0.81$ a to $2002 \pm 0.81 \mathrm{~d})$. The highest value was observed as $(2002 \pm 0.81 \mathrm{a})$ at study area 4, Wallay wala while the lowest value of total dissolved solids was observed as $(1810 \pm 0.81 \mathrm{~d})$ at study area 1 , Nagar village. The sand composition in soil samples collected from the study areas ranged between $(92.56 \pm 0.03 \mathrm{a}$ to $57.21 \pm 0.03 \mathrm{~d})$. The highest value was observed as $(92.56 \pm 0.03 a)$ at study area 4, Wallay wala while the lowest value of sand was observed as $(57.21 \pm 0.03 \mathrm{~d})$ at study area 5, surroundings of leather tanning industry. The silt composition in soil samples ranged between $(22.38 \pm 0.05$ a to $35.77 \pm 0.05 \mathrm{~d})$. The highest value for silt composition was noted as $(35.77 \pm 0.05 \mathrm{a})$ at study area 1 , Nagar village while the lowest value was noted as $(22.38 \pm 0.05 \mathrm{~d})$ at study area 4 , Wallay wala. The composition of clay in the soil sample collected from the study areas ranged between $(2.79 \pm 0.07 \mathrm{a}$ to $3.67 \pm 0.07 \mathrm{~d})$. The highest value was observed as (3.67 \pm 0.07 a) at study area 3, Ganda-Singh wala while the lowest value of clay was observed as $(2.79 \pm 0.07 \mathrm{~d})$ at study area 4 , wallay wala.

\section{CONClusion}

During the present study, the results showed that natural ecosystems of country are in tremendous pollution pressures. The obtained data will help the aquaculture scientists to understand the status of heavy metals accumulation in aquatic plants, associated soils and water, being parts of freshwater ecosystem. The aquatic plants have proved themselves for lowering the heavy metal pollution from associated water and soil. 


\section{SUGGESTIONS}

As aquatic plants are efficient in absorbing and accumulating the heavy metal traces from water. It is suggested to use the aquatic plants for lowering the heavy metal pollution from associated water and soil of freshwater ecosystems and wetlands. The proximate analysis of aquatic plants showed that these plants can also be used as animal feed supplement to decrease the protein loads from feed manufacturing industry.

\section{REFERENCES}

[1] Agunbiade FO, Olu-Owolabi BI, Adebowale KO. 2009. Phytoremediation potential of Eichornia crassipes in metal-contaminated coastal water. Biores Tech. 100(19):4521-6.

[2] Akmal M, Hafeez-ur-Rehman M, Ullah S, Younus N, Khan KJ, Qayyum M. 2014. Nutritive value of aquatic plants of Head Baloki on Ravi River, Pakistan. Int J Biosci. 4(10):115-22.

[3] Akpor OB, Muchie M. 2010. Remediation of heavy metals in drinking water and wastewater treatment systems: Processes and applications. Int J Phy Sci. 5(12):1807-17.

[4] Alvarado S, Guédez M, Lué-Merú MP, Nelson G, Alvaro A, Jesús AC, Gyula Z. 2008. Arsenic removal from waters by bioremediation with the aquatic plants Water Hyacinth (Eichhornia crassipes) and Lesser Duckweed (Lemna minor). Biores Tech. 99(17):8436-40.

[5] Barznji DA. 2014. Role of aquatic plants in improving water quality. UJPBS. 2(05):12-6.

[6] Bonanno G, Vymazal J, Cirelli GL. 2018. Translocation, accumulation and bioindication of trace elements in wetland plants. Sci Tot Environ. 631:252-61.

[7] Boule MK, Vicente JA, Nabais C, Prasad MN, Freitas H. (2009). Ecophysiological tolerance of duckweeds exposed to copper. Aqua Toxi. 91(1):1-9.

[8] Brix H. 1997. Do macrophytes play a role in constructed treatment wetlands? Water Sci Tech. 35: 1117.

[9] Chambers PA, Lacoul P, Murphy KJ, Thomas SM. 2008. Global diversity of aquatic macrophytes in freshwater. Hydrobiologia, vol., 595, no. 1, p. 9-26.

[10] Chandra P, Sinha S, Rai UN. 1997. Bioremediation of chromium from water and soil by vascular aquatic plants. Phytoremediation of soil and water contaminants. 274-82.

[11] Chen H, Shao Y, Xu Z, Wan H, Wan Y, Zheng SH, Zhu D. 2011. "Effective catalytic reduction of Cr (VI) over TiO2 nanotube supported Pd catalysts. Applied Catalysis B": Environ, vol. 105, pp. 255-262.

[12] Danh LT, Truong P, Mammucari R, Tran T, and Foster N. 2009. Vetiver grass, Vetiveria zizanioides: a choice plant for phytoremediation of heavy metals and organic wastes. Int $\mathrm{j}$ phytorem, 11(8): 664-691.

[13] David Tin Win, Than Myint Myint and Tun Sein 2003. Lead removal from industrial waters by water hyacinth. AU J. T., 6(4):187-192.

[14]Deng H, Ye ZH, Wong MH. 2004. Accumulation of lead, zinc, copper and cadmium by 12 wetland plant species thriving in metal-contaminated sites in China. Environmental pollution.132 (1):29-40.

[15] Dhote S, Dixit S. 2007. Role of macrophytes in improving water quality of an aquatic ecosystem. J App Sci Environ Manag. 1(4):131-5.

[16] Doyle, R.D. 2000. Effects of sediment resuspension and deposition on plant growth and reproduction. US Army Corps of Engineers, Rock Island, IL, USA. Environ Rep. 28. 64 pp.

Citation: Muhammad Usman Taj \& Sumaira Abass. "Proximate Analysis and Heavy Metal Detection in Aquatic Plants of River Satluj, District Kasur”. International Journal of Innovative Studies in Aquatic Biology and Fisheries, 5(3), pp.12-15.http://dx.doi.org/10.20431/2454-7670.0503002

Copyright: (C) 2019 Authors. This is an open-access article distributed under the terms of the Creative Commons Attribution License, which permits unrestricted use, distribution, and reproduction in any medium, provided the original author and source are credited. 